\title{
DESIGNING ENERGY EFFICIENCY GLAZED STRUCTURES WITH COMFORTABLE MICROCLIMATE IN NORTHERN REGION
}

\author{
Viktor Pukhkal \\ Andrii Bieliatynskyi \\ National Aviation University, Kyiv, Ukraine \\ Vera Murgul \\ St. Petersburg State Polytechnical University, St. Petersburg, Russia
}

St. Petersburg State University of Architecture and Civil Engineering, St. Petersburg, Russia

With the rising demand for entirely glass facades and glass roofs, the need to carry out an additional analysis of conditions to secure comfortable microclimate has appeared. There is a peculiar issue to work out design principles of glass buildings in the northern regions. The article deals with the general data of inside temperature in rooms and on internal glass surface of commercial pavilions made of glass. The data to work out the design of glazing for considerable areas of glass facades and glass roofs in the northern regions have been given herein. The factors, which make it uncomfortable for people to stay inside glass space, have been researched.

Heat losses in commercial pavilions with various dimension ratios and the amount of energy consumed for heating have been determined in the case of the weather conditions in the northern city of Saint-Petersburg (Russia).

Keywords: Translucent structures, Energy efficiency, Building, Glass, Construction

\section{INTRODUCTION}

Facades made of glass are very popular nowadays. They look stylishly and perfectly suit the modern architecture of the cities, and lightweight prefabricated structures with glass fillings provide quick installation [16]. Most of conducted researches of glazed buildings relate to the problem of overheating and passive usage of solar heat [09-10]. A great number of researches are devoted to the correlation between geometry shape of glazed buildings and their energy efficiency characteristics [15-02]. Insufficient attention is paid to the problem of applying glazed external structures in northern regions. Popularity of glass buildings demanded an additional analysis of comfortable microclimate provision problem in them. The necessity of generalization and systematization of methodologies for a comfortable human residence appeared for buildings which have significant areas of facade or roof glazing in the northern regions.

Glass surfaces are the most problem areas of external structures due to high thermal losses in the winter period. Thus, developing methods of improving their thermal insulating properties is becoming actual [17].
Another issue to be taken into account when designing glass structures is related to the low temperature values of interior glass surfaces in the winter periods of the year if to compare with the temperature values of the elements of other building envelope surfaces thereby resulting in uncomfortable conditions for people in the area close to windows. According to the survey results the majority of people working in office facilities with the facades made of glass or living in flats with panoramic windows feel uncomfortable to a significant extent in cold seasons due to a feeling of 'exposure to cold' coming from glass windows in winter time [08]. This issue with the reference to commercial pavilions based on glass structures will appear to be more crucial as almost all the envelopes have lower temperature values.

\section{MATERIALS AND METHODS}

\section{Temperature and humidity requirements for} glass buildings

On the basis of the analysis performed to evaluate usage and maintenance conditions of the build- 
ings with considerable areas of glass facades and glass roofs, heat losses in buildings and the amount of energy consumed for heating of pavilions with various dimension ratios have been determined using the computational method.

Exhibition and commercial pavilions based on glass structures were taken for consideration (Figure 1).

Internal air parameters are standardized only for work area of a room. Work area is the area in a room confined between two planes, which are parallel to the walls and a floor: at the heights of 0.1 and $2.0 \mathrm{~m}$ above floor level (no closer than 1 $\mathrm{m}$ from a ceiling in case of ceiling heating), at the distance of $0.5 \mathrm{~m}$ to be measured from internal surfaces of interior and external walls, windows and heaters (Figure 2).

The comfort of the microclimate in glazed buildings in winter period is defined by the regulations of heat exchange between human body and an internal environment of the room and glazed external structures [12].

a)

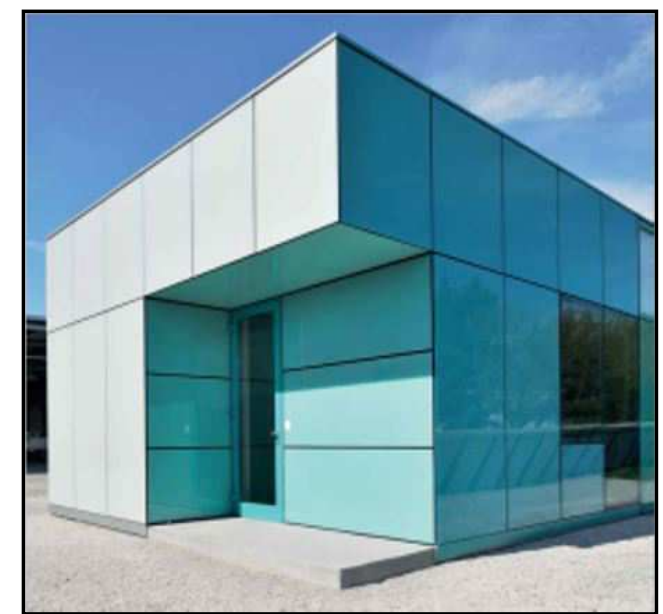

b)

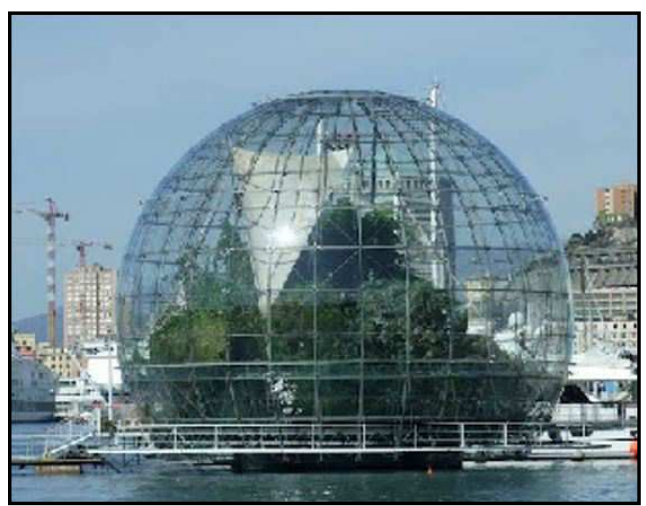

Figure 1: a) Exhibition pavilion (Slovenia), b) Botanic garden 'Biosphere' (Italy)

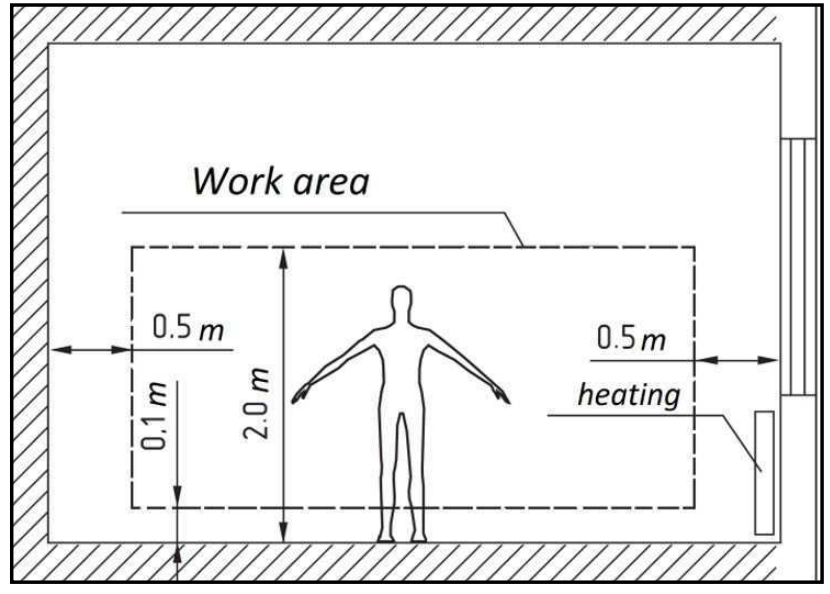

Figure 2: Work area in a room

There are the following standards for interior climate parameters in rooms [10]:

- internal air temperature, $t_{\text {int }},{ }^{\circ} \mathrm{C}$;

- resultant temperature, $t_{\text {res }},{ }^{\circ} \mathrm{C}$;

- relative humidity of internal air, $\varphi_{\text {int }}, \%$;

- air velocity in a room, $W_{\text {int }}, \mathrm{m} / \mathrm{c}$.

Two parameters - air temperature and temperature of the surfaces around a room - are exposed to achieve comfortable temperature in the systems assigned for heating. The combination of the temperatures of the surface around a room and air form the resultant temperature which is to be determined as follows:

$t_{\text {res }}=\frac{t_{\text {int }}+t_{R}}{2}{ }^{\circ} \mathrm{C}$

where $t_{R}$ - radiant temperature of a room (average temperature of the surfaces in a room), ${ }^{\circ} \mathrm{C}$; - at the air velocity starting from 0.2 up to $0.6 \mathrm{~m} / \mathrm{s}$.

$t_{\text {res }}=0.6 t_{\text {int }}+0.4 t_{R}^{\circ} \mathrm{C}$

The values of the optimal resultant temperature in the cold period of the year are the following $-18-20^{\circ} \mathrm{C}$ above zero.

Glazing surfaces in a room will be determinant for comfortable conditions in winter time.

When the temperature of the internal glass goes down up to $10^{\circ} \mathrm{C}$ human heat losses due to the radiation towards usual windows of an ordinary building may reach the values 5 times more than a lower boundary point of heat or cold that a person can feel [08]. Consequently, this effect will increase with the increase of external glazing area in a building with totally glazed facades.

An average temperature of internal surfaces of translucent structures depends on a heat release 
rate of an internal glazing surface and thermal resistance.

$\tau_{\text {int }}=t_{\text {int }}-\frac{t_{\text {int }}-t_{\text {ext }}}{\alpha_{\text {int }}} U$

where $T_{\text {int }}$ - average temperature of an internal glazing surface, ${ }^{\circ} \mathrm{C}$;

$\mathrm{t}_{\mathrm{int}}$ - air temperature in a room, ${ }^{\circ} \mathrm{C}$;

$\mathrm{t}_{\text {ext }}$ - external air temperature, ${ }^{\circ} \mathrm{C}$;

$\alpha_{\text {int }}$ - heat release rate of an internal surface of an envelope, $\mathrm{W} /\left(\mathrm{m}^{2}{ }^{\circ} \mathrm{C}\right)$;

$U$ - heat transfer factor of a translucent structure, $\mathrm{W} /\left(\mathrm{m}^{2} \cdot{ }^{\circ} \mathrm{C}\right)$.

Calculation results regarding the temperatures of an internal glazing surface in relation to various values of a heat transfer factor for windows and external temperature values having temperature in a room equal to $20^{\circ} \mathrm{C}$, are given in the Table 1. The calculations have been made for the central area of a glass unit with a boundary area excluded.

When making thermotechnical calculations for translucent structures it is necessary to consider thermal resistance in a relation area of a glass unit and non-uniformity of their temperature fields. The temperature of the surfaces of boundary areas in regard to the glass unit (at the distance up to $200 \mathrm{~mm}$ from a spacer frame) from the room's side is determined under the following formula:

$\tau_{\text {int }}^{b}=t_{\text {int }}-\frac{t_{\text {int }}-t_{\text {ext }}}{\alpha_{\text {int }} k_{\ddot{A}}} U$

where $k_{\tau}$ - the factor which considers changes of values $U$ and at different points of the vertical and horizontal sections of the glass unit boundaries, and is to be determined according to the Table 2.

For instance, the calculation results for the relation (4) in regard to the temperature of the surface of the double-glazed window having a wooden sash with due account for boundaries are presented in the Figure 4 . The following values are assumed: $\alpha_{\mathrm{int}}=8.7 \mathrm{~W} /\left(\mathrm{m}^{2}{ }^{\circ} \mathrm{C}\right) ; \mathrm{t}_{\mathrm{int}}=20$ ${ }^{\circ} \mathrm{C} ; \mathrm{t}_{\text {eet }}=-10^{\circ} \mathrm{C} ; \mathrm{U}=2.0 \mathrm{~W} /\left(\mathrm{m}^{2 \circ} \mathrm{C}\right)$; the glass unit dimensions - $3000 \times 3000 \mathrm{~mm}$. The data obtained accurately coincide with the data given in the article [03] and defined in accordance with the results of the thermal imaging made for internal surfaces of glass units. The temperature of the surface in the boundary area of a glass unit changes with due account for a type of a spacer frame and a glass unit configuration [05]. The values of the temperature in boundary areas of the glass units in accordance with the different types of spacer frames [11] are shown in the Table 3 and in the Figure 5.

Table 1. Temperature of an internal glazing surface to external air temperature relation

\begin{tabular}{|c|c|c|c|c|c|c|}
\hline $\begin{array}{c}\text { External air } \\
\text { temperature, } \\
{ }^{\circ} \mathrm{C}\end{array}$ & \multicolumn{7}{|c|}{$\begin{array}{c}\text { Temperature of an internal glazing surface in relation to a heat transfer factor of a glass } \\
\text { structure }{ }^{\circ} \mathrm{C}\end{array}$} \\
\hline & 0,3 & 0,4 & 0,5 & 1,0 & 2,0 & 2,5 \\
\hline 0 & 19.3 & 19.1 & 18.9 & 17.7 & 15.4 & 13.1 \\
\hline-10 & 19.0 & 18.6 & 18.3 & 16.6 & 13.1 & 9.7 \\
\hline-20 & 18.6 & 18.2 & 17.7 & 15.4 & 10.8 & 6.2 \\
\hline-30 & 18.3 & 17.7 & 17.1 & 14.3 & 8.5 & 2.8 \\
\hline
\end{tabular}

Table 2. The factor $k_{\tau}$ which considers the temperatures of the boundary areas of the glass units

\begin{tabular}{|c|c|c|c|c|c|c|c|}
\hline \multirow{2}{*}{$\begin{array}{l}\text { Configuration and material } \\
\text { of a window sash }\end{array}$} & \multirow{2}{*}{$\begin{array}{l}\text { Section } \\
\text { along the glass unit }\end{array}$} & \multicolumn{6}{|c|}{$\begin{array}{l}\text { Factor } k_{T} \text { the glass unit at the destination starting from a } \\
\text { spacer frame, }[\mathrm{mm}]\end{array}$} \\
\hline & & 5 & 25 & 50 & 100 & 150 & 200 \\
\hline \multirow{3}{*}{ Wood } & Upper vertical & 1.05 & 1.2 & 1.26 & 1.16 & 1.06 & 1.02 \\
\hline & Lower vertical & 0.62 & 0.72 & 0.82 & 0.91 & 0.96 & 0.98 \\
\hline & Horizontal & 0.75 & 0.87 & 0.95 & 0.98 & 0.99 & 1.00 \\
\hline \multirow{3}{*}{ Aluminum } & Upper vertical & 0.93 & 1.09 & 1.21 & 1.14 & 1.05 & 1.02 \\
\hline & Lower vertical & 0.59 & 0.7 & 0.81 & 0.90 & 0.95 & 0.98 \\
\hline & Horizontal & 0.67 & 0.84 & 0.94 & 0.97 & 0.99 & 1.00 \\
\hline
\end{tabular}


Table 3. Surface temperature in boundary areas of the glass units with different spacer frames at the temperature internal air $20^{\circ} \mathrm{C}$ above zero

\begin{tabular}{|c|c|c|c|c|c|c|}
\hline \multirow{2}{*}{ External air temperature, $\left[{ }^{\circ} \mathrm{C}\right]$} & \multicolumn{4}{|c|}{ Surface temperature in boundary areas of the glass units, $\left[{ }^{\circ} \mathrm{C}\right]$} \\
\cline { 2 - 6 } & \multicolumn{2}{|c|}{ one-chamber glass } & \multicolumn{3}{|c|}{ Double-glazed } \\
\cline { 2 - 6 } & $\mathrm{AL}^{*}$ & $\mathrm{RST}^{*}$ & $\mathrm{SWS}^{*}$ & $\mathrm{AL}$ & $\mathrm{RST}$ & $\mathrm{SWS}$ \\
\hline 0 & 11.0 & 11.9 & 13.3 & 11.5 & 12.2 & 13.8 \\
\hline-10 & 6.7 & 7.7 & 10.0 & 7.2 & 8.3 & 10.8 \\
\hline-20 & 2.3 & 3.6 & 6.6 & 3.0 & 4.4 & 7.5 \\
\hline-30 & -2.2 & -0.4 & 3.2 & -1.3 & 0.5 & 4.4 \\
\hline
\end{tabular}

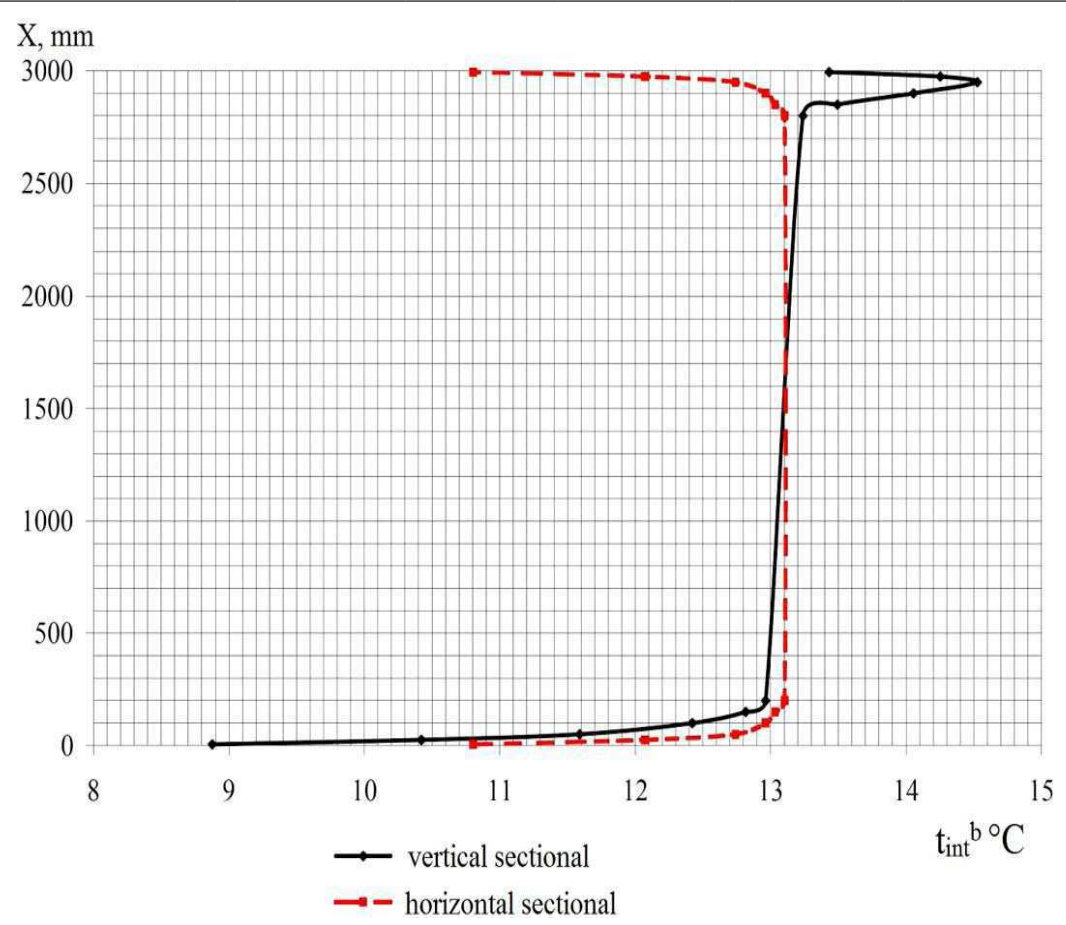

Note: Data given for the glass units with the aluminum spacer frames.

Figure 4: Internal surface temperature fields for the double-glazed widow with a wooden sash (X-distance form a lower or a side spacer frame of the glass unit, $\mathrm{mm}$ )

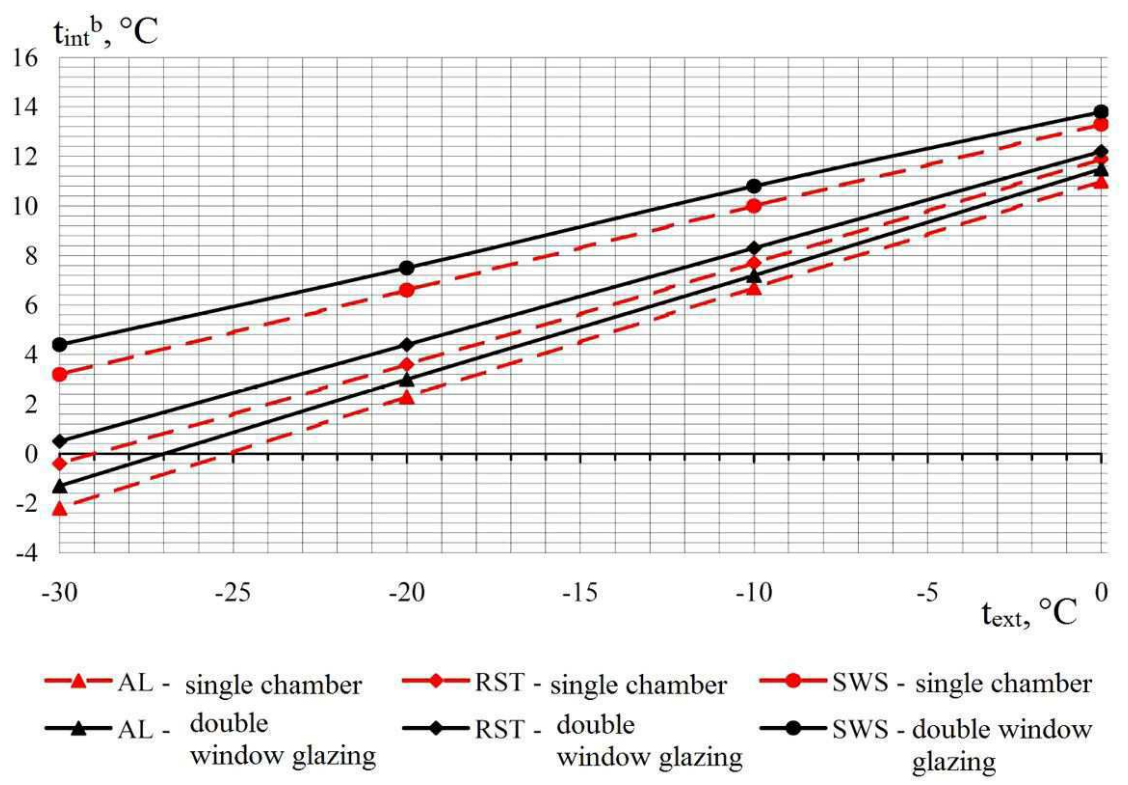

Figure 5: Surface temperature in boundary areas of the glass units with different spacer frames at the internal air temperature $20^{\circ} \mathrm{C}$ above zero 
The following should be considered when designing translucent structures:

- the value of a heat transfer factor of a glass unit is given for the central area of a vertical glass unit in the specifications stated by a manufacturer;

- the value of a heat transfer factor for the glass unit boundaries in accordance with the type of a space frame used is $0.1-0.3$ $\mathrm{W} /\left(\mathrm{m}^{2} \cdot{ }^{\circ} \mathrm{C}\right)$ more than for the central area. Depending on the configurations and dimensions of the glass units the boundary area accounts for nearly $2-4 \%$ out of total area of a translucent structure;

- the value of a heat transfer factor of the glass unit profile system usually is within the limits of $1-1.5 \mathrm{~W} /\left(\mathrm{m}^{2}{ }^{\circ} \mathrm{C}\right)$, and its share in a total area of a translucent structure also depends on the dimensions and the configuration of the cells and amounts to $2-4 \%$;

- the value of a heat transfer factor of the glass units placed horizontally or at an angle of, $\leq 20^{\circ}$ is significantly higher than the one for the vertically placed glass units - nearly $30-70 \%$ [11].

Lower temperature of internal surface of glazing comparing to average temperature in the room leads to 3 effects which create discomfort:

1. Cold air flow near the glazing. Cold air flow which appears on the glass surface lowers from the window and spreads around the floor.

2. Radiation heat transfer between human and external glass structures. Cold surface of the window leads to the unpleasant cooling of human body.

3. Formation of the condensate on the internal surface of the glazing. During the cooling of air layer which adjoins the glazing, it's temperature can become lower than the dew point, which leads to the condensate appearing on the internal surface of the building. Mentioned effects could be prevented with certain actions or at least their impact can be reduced

\section{RESULTS AND DISCUSSION}

\section{Cold air flow near the glazing}

Temperature comfort in the working space depends on speed of air flow. The calculated air speed, substantiated by the action of a pulldown flow near the window should not exceed the standard values.

The maximum value of the air current velocity which emerges near an envelope due to free convection and goes along the floor of the room is determined by the following relation [06]

$w_{\max }=3.33 w_{0}\left(\frac{b_{0}}{l}\right)^{0.5}$

where $w_{0}$ - average velocity in initial section of an air current along the area (near an envelope), $\mathrm{m} / \mathrm{s}$;

$b_{0}-$ width of an air current in initial section, $\mathrm{m}$;

$\mathrm{l}$ - distance from an envelope, $\mathrm{m}$.

Average velocity in initial section of an air current along the area

$w_{0}=0.061\left(t_{\text {int }}-\tau_{\text {int }}\right)^{0.5} H^{0.5}$

where $H$ - height of glazing, $\mathrm{m}$.

Width of an air current in initial section

$b_{0}=0.071\left(t_{\text {int }}-\tau_{\text {int }}\right)^{-0.167} H^{0.5}$

Calculation results for the maximum value of the air current velocity at the distance of $0,5 \mathrm{~m}$ from the envelope in accordance with the relations (3) - (5) are given in the Figure 6.

For instance, the temperature of the internal glazing surface for a double-glazed unit with the heat transfer factor equal to $2 \mathrm{~W} /\left(\mathrm{m}^{2} \cdot{ }^{\circ} \mathrm{C}\right)$ and the external air temperature $10{ }^{\circ} \mathrm{C}$ below zero, accounts for $13.1^{\circ} \mathrm{C}$. Then, with $t_{\text {int }}-T_{\text {int }}=20-13.1=6.9$ and the glazing unit height $\mathrm{H}=3 \mathrm{~m}$ the maximum air current at the distance of $0.5 \mathrm{~m}$ form the envelope will be equal to $0.39 \mathrm{~m} / \mathrm{s}$. The optimal air velocity - no more than $0.2 \mathrm{~m} / \mathrm{s}$; and the accessible one - no more than $0.3 \mathrm{~m} / \mathrm{s}$ [01]. Consequently, it is necessary to take into account all the measures required for to safeguard the work area of the room against the cold air flow.

It should be noted that there are a lot of relations with varied velocity values which can be used to calculate the maximum air current velocity which emerges near the envelope due to free convection and goes along the floor in the room. According to the article [08] the following relation for the distance from the envelope within the limits of $0.4-2 \mathrm{~m}$ is given herein:

$w_{\max }=0.095 \frac{\left(t_{\text {int }}-\tau_{\text {int } 2}\right)^{0,5} H^{0,5}}{l+1.32}$ 
resulting in the velocity value equal to $w_{\max }=0.24$ $\mathrm{M} / \mathrm{c}$. This divergence can be explained by the difference in the relation calculation approaches and accuracy in experimental research data.

According to the authors the calculations should be made in compliance with the relations (5) - (7) that ensures better climate conditions in the work room.

The air flow velocity near the windows exceeds the one required under sanitary and hygienic requirements by 2 times. It would be rational to install the heaters under the windows.

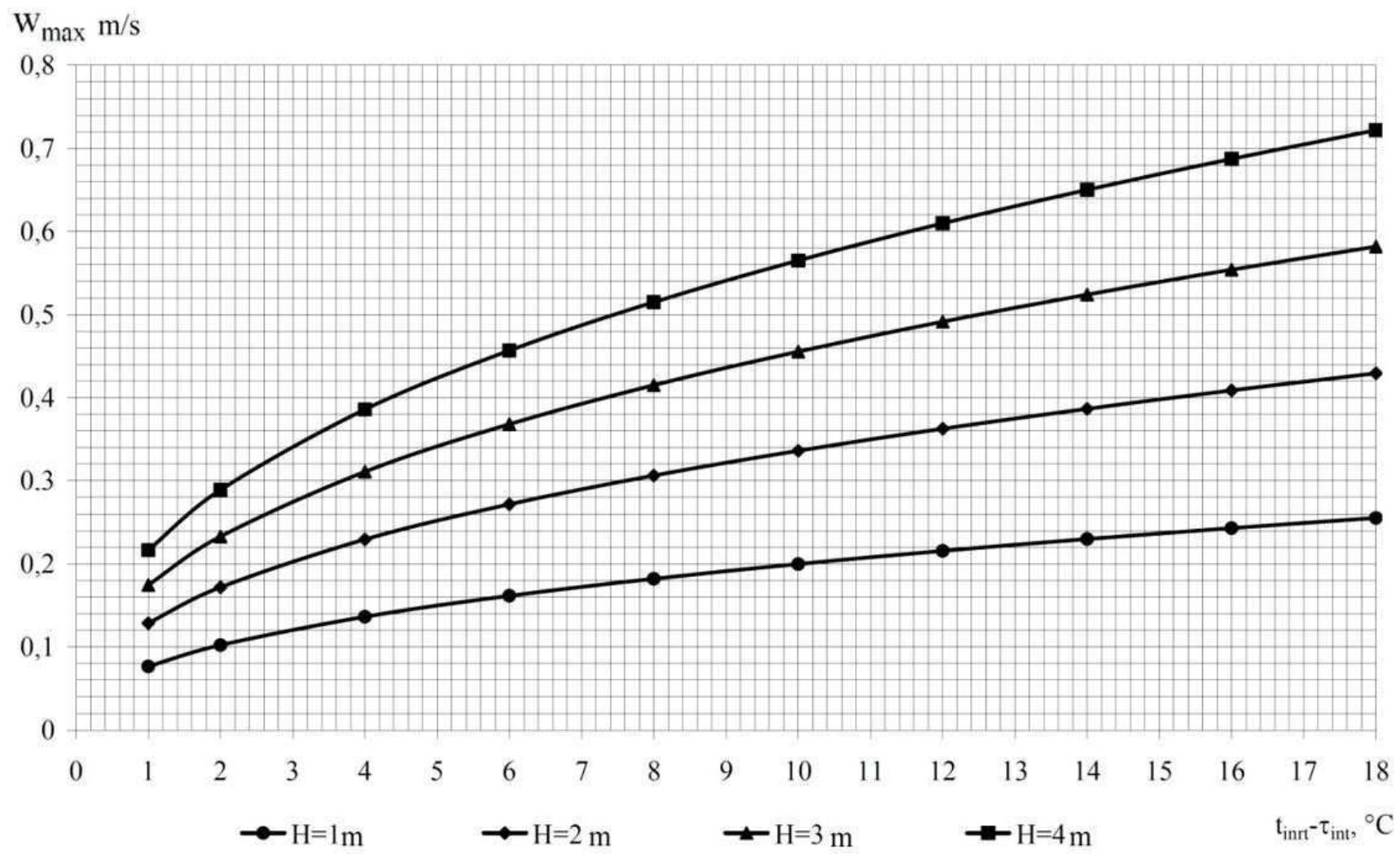

Figure 6: Relation of the maximum air current velocity at the distance of $0.5 \mathrm{~m}$ of the envelope to the temperature difference between internal air and air in the area of glazing surface and to height of glazing units

\section{Radiation heat transfer between human and external glass structures}

Human heat losses caused by radiation can be determined by a temperature of an internal glazing surface, dimensions of the glazing and a person's position in relation to light openings.

Accessible internal glazing surfaces temperatures are determined by the relation [06]:

$\tau_{\text {int } . p}=14-\frac{3.5}{\phi_{h-w}}{ }^{\circ} \mathrm{C}$

where $\varphi_{h-w}$ - the factor of heat radiation emitted from human skin on the glazing surface.

Heat radiation factor is [19]

$\phi_{h-w}=1-\frac{0.8}{F_{w}^{0.5}}$

where $F_{w}$ - glazing area, $\mathrm{m}^{2}$.
Exhibition halls are normally five-sided glazing systems (only floor is not glazed).

For this reason the value of a heat radiation factor can be assumed to be roughly equal to 1 ( $\left.\varphi_{h-w}=1\right)$. Then the temperature of internal surfaces is equal to $T_{\text {int.p }}=14-3.5=10.5^{\circ} \mathrm{C}$. According to the relation (1) it is possible to find out that the value of the heat radiation factor with the estimated temperature of the external air equal to

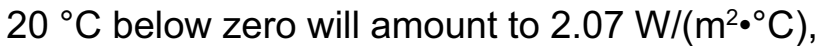
and correspondingly with the temperature equal to $30{ }^{\circ} \mathrm{C}$ below zero $-1.65 \mathrm{~W} /\left(\mathrm{m}^{2} \cdot{ }^{\circ} \mathrm{C}\right)$.

Human skin heat radiation emitted on cold glazing surfaces can be balanced with warm surfaces located at or under cold surfaces.

\section{Formation of the condensate on the internal surface of glazing}

Moisture condensation occurs in a boundary layer which is right at an envelope's surface. 
Dew point temperature of the air in the room at the temperature of $20{ }^{\circ} \mathrm{C}$ above zero with the relative humidity $50 \%$ accounts for $9.3{ }^{\circ} \mathrm{C}$. If to compare glazing surface temperatures (Table 1) with the dew point temperature one may find out that there is a low risk of condensation in the central area under these conditions when using gazed units with the low heat transfer rate since the temperature of glazing is higher than the dew point temperature.

Owing to the lower temperature of the glazed units' boundaries condensation quite often occurs in the area of boundaries. There is risk of condensation in case of one-chamber glass units with the aluminum spacer frames when the temperature of the external air is lower than $3^{\circ} \mathrm{C}$ below zero. And there is risk of condensation in case of double-glazed units with the composite frames when the temperature of the external air is equal to or lower than $13.5^{\circ} \mathrm{C}$.

The temperature of boundaries may be changed if another type of a spacer frame is used and if the window frame profiles are changed.

When designing vertical or horizontal surfaces at an angle to the horizon, glass heat radiation towards sky should be taken into account as it can cause condensation or ice formation (in most cases at nights). In this case it is suggested that an external glass with a low emission rate and with a 'rigid' surface faced outward - and, not inward - (as it is normally accepted in standard options) should be applied [08].

Condensation may be avoided if cooling of the air is prevented up to the dew point temperature owing to the warm air, or the dew point temperature is changed due to the drier air move to the glazing surfaces.

\section{Heat losses of commercial halls based on glass structures}

The parameters of thermal and humidity conditions in could time of a room are determined by heat capacity of a heating system and thermal insulation parameters of building envelopes (in general cases - exterior walls with one or more windows) [04].

Let's consider heat losses of an commercial hall due to heat transfer through glazing envelope structures (coating and exterior walls) of an exhibition hall with regard to the environment conditions in case of Saint-Petersburg:
- internal air temperature $-t_{\text {int }}=18^{\circ} \mathrm{C}$;

- external air temperature $-t_{\text {ext }}=-24^{\circ} \mathrm{C}$.

When making computations extra heat losses, which are related to building envelopes orientation and external infiltrating air heating, are taken into account.

The exhibition hall is made of translucent structures Qbiss Air [07] shown in the Figure 1. The glass modular façade system "Qbiss Air» is the multilayer insulation façade system with the following parameters:

- the heat transfer factor of the structural module with seven layers $-U=0.19 \mathrm{~W} /\left(\mathrm{m}^{2}{ }^{\circ} \mathrm{C}\right)$;

- the heat transfer factor of the translucent structure (including boundaries, profile systems and horizontal systems $)-U=0.27$ $-0.45 \mathrm{~W} /\left(\mathrm{m}^{2} \cdot{ }^{\circ} \mathrm{C}\right)$;

- an assumed heat transfer factor for the facade glazing $-\mathrm{U}=0.4 \mathrm{~W} /\left(\mathrm{m}^{2}{ }^{\circ} \mathrm{C}\right)$;

- an assumed heat transfer factor for the roof glazing $-\mathrm{U}=0.32 \mathrm{~W} /\left(\mathrm{m}^{2} \cdot{ }^{\circ} \mathrm{C}\right)$.

Heat losses through building envelopes can be determined according to the following relation

$Q=\sum_{i=1}^{n} F_{i} \cdot\left(t_{\mathrm{int}}-t_{\text {ext }}\right) \cdot U_{i}$,

where $F_{i n t}$ - an estimated area of the envelope 'i', $m^{2}$.

Calculation results related to heat losses through building envelopes with the dependence on the pavilion's volume and the ratio of total envelopes area $\left(F, m^{2}\right)$ to the pavilion's volume $\left(\mathrm{V}, \mathrm{m}^{3}\right)$ are shown in Figure 7.

A specific annual consumption of heat energy meant for heating per $1 \mathrm{~m} 2$ of the floor area of the pavilion is specified in Fig. 8. When calculating specific energy consumption a 12-hours daily work is taken. Heating system operates at nights with reduced energy consumption and ensures the temperature of the internal air equal to $5{ }^{\circ} \mathrm{C}$ ('background heating'). 
Q, W

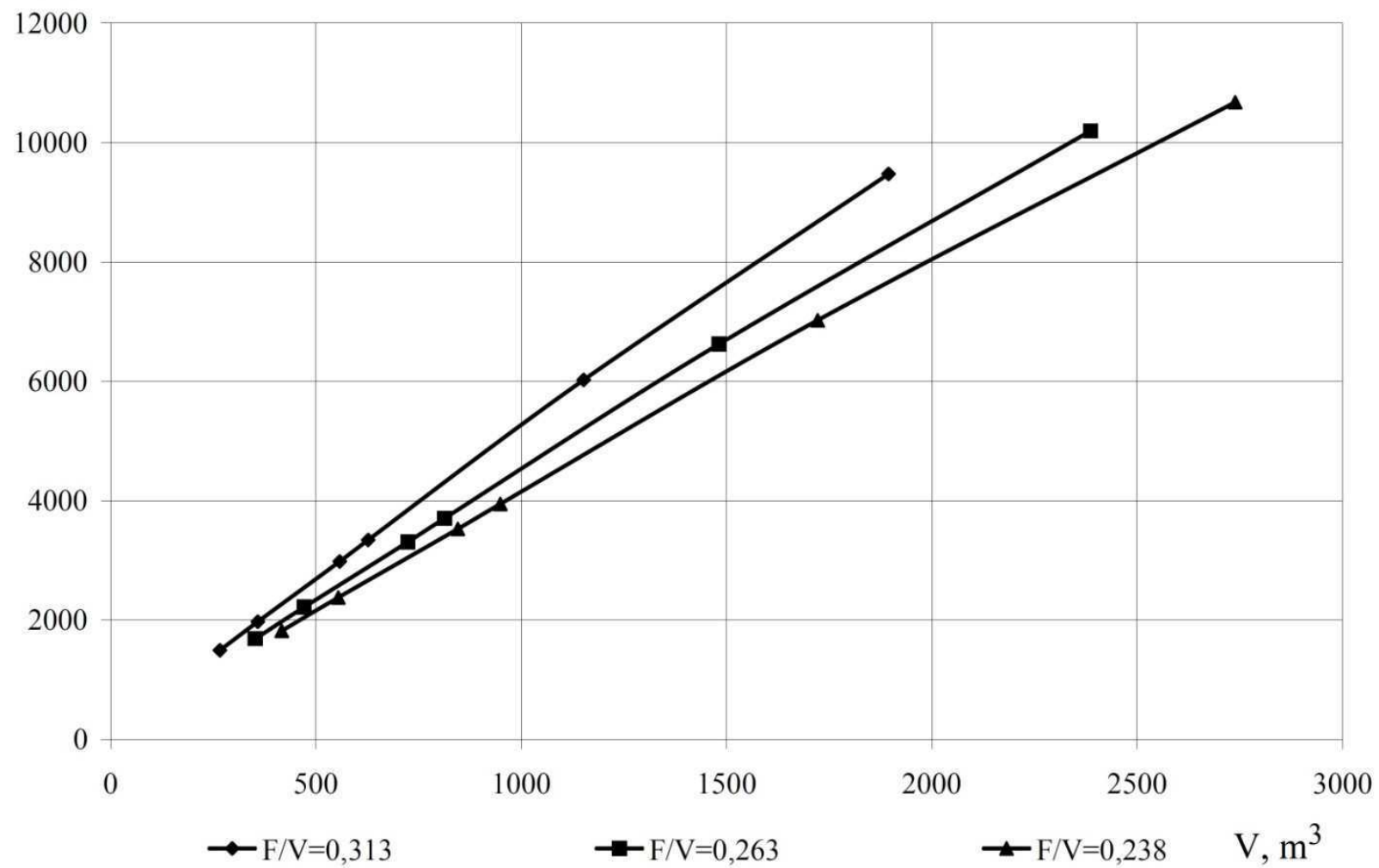

Figure 7: Heat losses in an commercial hall.

$\mathrm{q}, \mathrm{kW} \cdot \mathrm{h} / \mathrm{m}^{2}$

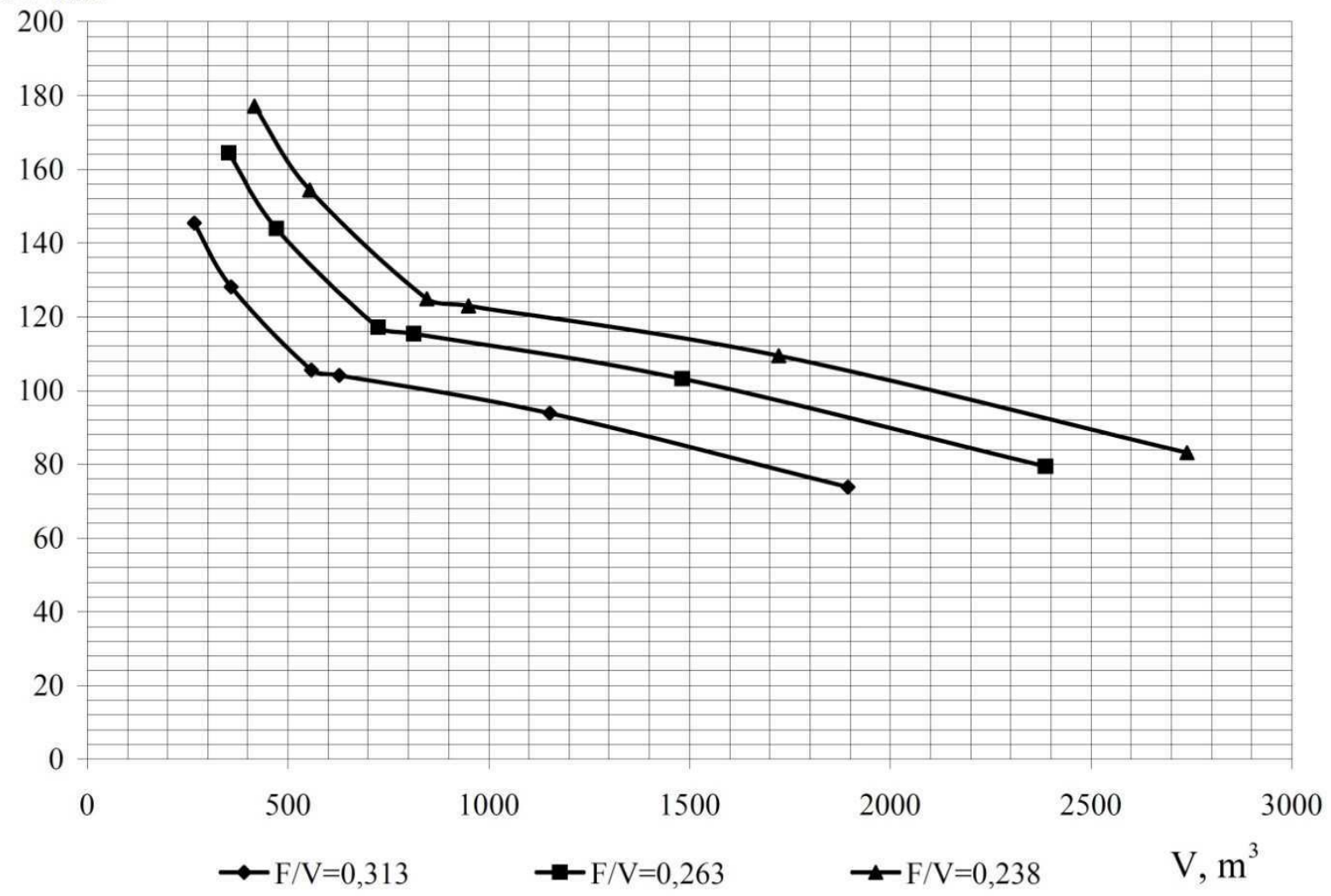

Figure 8: Specific annual consumption of heat energy for heating 


\section{CONCLUSION}

1. Data about the temperature regime indoors and at the internal surface of the glazing was generalized for the exhibition and trade pavilions made of glass.

2. Information for designing of glazing is exposed, considering winter conditions of building exploitation, which have significant areas of facade or roof glazing

3. Factors which create the discomfort among the people in a room with a large glazed area were analyzed:

- the flow of a cold air which appears on the cold surface of the window and goes down spreading around the floor

- human radiation heat transfer with the external glass structures;

- formation of the condensate on the internal surface of glazing

4. Heat losses of exhibition pavilions with different ration of sizes and energy consumption of heating systems for Saint-Petersburg (Russia).

\section{REFERENCES}

1) Babiak, J., Olesen, B.W., Petráš, D. (2013): Low Temperature Heating and High Temperature Cooling Embedded. Water Based Surface Heating and Cooling Systems, Guidebook 7, REHVA.

2) Boriskinoj, I.V. (2012): Buildings and structures with translucent facades and roofs. Theoretical bases of designing of glass constructions, St. Petersburg: Stroyizdat.

3) Garber-Slaght, R., Craven, C. (2012): Evaluating window insulation for cold climates. Journal of Green Building, 7, p. 32.

4) GOST 30494-2011. Residential and public buildings. Options indoor climate, Moscow, Publisher: Standartinform, $12 \mathrm{p}$.

5) Guidelines for the calculation of translucent constructions of buildings (2006) NIISF. Moscow: Strojizdat.

6) http://www.trimo.si/media/qbiss-air-brochure-en 23006.pdf (retrieved on November 7th, 2015).

7) Huang, Y., Niu, J. (2015): Application of super-insulating translucent silica aerogel glazing system on commercial building envelope - Impact on space cooling load, Energy, 83, pp. 316-325.
8) Karlsson, J. (2001): Windows - Optical Performance and Energy Efficiency, Uppsala: Tryck \& Medier, SE, $57 \mathrm{p}$.

9) Korniyenko S.V. (2011): The estimation of enclosing structures edge zones influence on thermal performance and energy efficiency of buildings, Magazine of Civil Engineering, 8 (26), pp. 5-12.

10) Leskovar, V.Ž., Premrov, M. (2011): An approach in architectural design of energy-efficient timber buildings with a focus on the optimal glazing size in the south-oriented façade, Energy and Buildings, 43 (12), pp. 3410-3418.

11) Majorov V.A. (2014): The transfer of heat through the windows: Textbook, Moscow: Publisher ACB.

12) Mihalakakou, B. (2002): On the use of sunspace for space heating/cooling in Europe, Renewable Energy, 26, p. 415.

13) Parasonis, J, Keizikas, A and Kalibatiene, D. (2012): The relationship between the shape of a building and its energy performance, Architectural Engineering and Design Management, 8(4), pp. 246-256.

14) Parasonis, J., Keizikas, A. (2013): Increasing Energy Efficiency of the Translucent Enclosure Walls of a Building, Procedia Engineering, Vol. 57, pp. 869-875.

15) Parasonis, J., Keizikas, A., Endriukaityt, A., Kalibatien, D. (2012): Architectural solutions to increase energy efficiency of buildings, Journal of Civil Engineering and Management, 18, pp. 1-11.

16) Saukko T., Lejnonen L., Zuevskij K. Multifunctional glass electrically heated (2013) High-rise buildings, 5, pp. 90-95.

17) Wall, M. (1997): Distribution of solar radiation in glazed spaces and adjacent buildings. A comparison of simulation programs, Energy and Buildings, 26, p. 129.

18) Žegarac Leskovar, V., Premrov, M. (2012): Design approach for the optimal model of an energyefficient timber building with enlarged glazing surface on the south façade, Journal of Asian architecture and building engineering, vol. 11, no. 1, pp. 71-78.

Paper sent to revision: 01.02.2016.

Paper ready for publication: 15.03.2016. 


\section{Viktor Pukhkal, Državni Univerzitet Arhitekture i Građevine, St. Petersburg, Rusija}

Andrii Bieliatynskyi, Nacionalni Unoverzitet Avijacije, Kijev, Ukrajina

Vera Murgul, Državni Politehnički Univezitet, St. Petersburg, Rusija

S rastom popularnosti objekata sa potpuno staklenim fasadama i krovovima javlja se potreba za dodatnim analizama uslova obezbeđivanja konfortne mikro-klime u njima. Posebnim zadatkom javlja se razrada principa projektovanja staklenih objekata u severnim regionima. $U$ ovom radu su uopšteni podatci o temperaturnom režimu u prostorijama i na unutrašnjim površinama zastakljenih komercijalnih paviljona, izradjenih od stakla. Navedeni su podatci za projektovanje zastakljenja, koji imaju značajne površine fasadnog ili krovnog zastakljenja za severni region. Istraživani su faktori, koji stvaraju osećaj diskonforta kod ljudi u prostorijama sa značajnim zastakljenim površinama. Opredeljeni su toplotni gubitci komercijalnih paviljona sa različitim odnosima razmera i potrošnja energije njihovih sistema grejanja na primeru klimatskih uslova severnog grada Sankt-Petersburga (Rusija).

Ključne reči: Transparentne strukture, Energetska efikasnost, Zgrada, Staklo, Izgradnja 